Журба С. С. кандидат філологічних наук, доцент кафедри української та світової літератур ДВНЗ «Криворізький державний педагогічний університет»

\title{
ТРАГЕДІЯ УКРАЇНСЬКОГО СЕЛЯНСТВА ПІД ЧАС ГОЛОДОМОРУ У ПРОЗІ ДІАСПОРИ (на матеріалі творів Олени Звичайної та Іванни Чорнобривець)
}

У статті досліджено твори письменників діаспори Олени Звичайної та Іванни Чорнобривець на тему голодомору 1932-1933 рр. Акцентовано на специфіці авторського 
бачення етноииду, засобах та прийомах психологічного аналізу історичних реалій. На матеріалі оповідань розкрито екзистениійне буття людини в тоталітарному суспільстві, експресіоністичне відображення трагедії украӥнців.

Ключові слова: голодомор, історична правда, документальність, екзистенційність, натуралізм, психологізм.

The article deals the works of Diaspora's writers Olena Ordinary and Ivanna Chornobryvets on the theme of the Holodomor of 1932-1933. It focuses on the specifics of the author's vision of ethnocide, the means and techniques of psychological analysis of images, historical realities. The story tells about the existential existence of man in a totalitarian society, an expressionistic reflection of the tragedy of Ukrainians.

Key words: holodomor, historical truth, documentary, existentialism, naturalism, psychologism.

В статье проанализированы произведения писателей диаспоры Елены Звычайной и Иванны Чорнобривец на тему голодомора 1932-1933 г2. акцент сделан на специфике авторского видения этноцида, средствах и приемах психологического анализа исторических реалий. На материале рассказов раскрыт смысл бытия человека в тоталитарном обществе, экспрессионистическое отображение трагедии украинцев.

Ключевые слова: голодомор, историческая правда, документальность, экзистенциальность, натурализм, психологизм.

Загальнонаціональною трагедією став голодомор 1932-1933 років, визнаний актом геноциду українського народу країнами світу. Питання історичної правди довго замовчувалося у радянській Україні, натомість творився міф про радянську дійсність із щасливою людиною - будівником комунізму. Все ж письменники намагалися сказати про ті страшні часи, змальовуючи труднощі українських хліборобів у 1930-ті роки, зокрема М. Стельмах у романах «Чотири броди» та «Дума про тебе». Фрагменти зображення великої біди наявні у творі «Люди не ангели» російськомовного письменника I. Стаднюка. Згадує у своїх роздумах перед боєм голодний рік Роман Блаженко з роману Олеся Гончара «Прапороносці», розповідає про нього артилерист Решетняк 3 «Людини i зброї». Існують i серйозні науководокументальні дослідження як за кордоном, так і в Україні, в яких дається грунтовний історичний аналіз цієї соціальної катастрофи.

Тема голоду в українській літературі першої половини XX століття $\epsilon$ однією 3 найтрагічніших, до якої зверталися П. Тичина, В. Підмогильний, М. Куліш, А. Любченко, В. Барка, Ю. Клен, Т. Осьмачка, М. Руденко, А. Дімаров та інші, проте масштабно жахіття 1933 передав Улас Самчук у романі «Марія». Актуальність теми та історіософське осмислення причин голодомору, художня майстерність, щирість оповіді ставлять твір у ряд 
найвидатніших досягнень української прози XX століття. Документалізм та експресивність оповіді щодо змалювання трагічних сторінок історії задекларовані письменниками діаспори - Уласом Самчуком, Тодосем Осьмачкою, Василем Баркою, Докією Гуменною, Оленою Звичайною, Іванною Чорнобривець та іншими. У творах митців, на думку Світлани Ленської, тема голоду стала «болючим спогадом про жахіття, свідками якого їм випало стати на рідній землі, гірким роздумом про безталанну долю Украӥни» [Ленська 2015:367].

До осмисленням подій штучного голодомору 1932-1933 рр. у прозі Олени Звичайної та Іванни Чорнобривець у вітчизняному літературознавстві побіжно зверталися Світлана Ленська, Наталя Шумило. У дослідженні «Українська мала проза 1920-1960-х років: ідейно-тематичні домінанти, жанрові моделі і стильові стратегії» Світлана Ленська акцентує на трагедії українського селянства, осмислює Голодомор як національну катастрофу у новелістиці діаспори, а також грунтовно простежує інтертекстуальні зв’язки повісті Олени Звичайної із творами Миколи Гоголя, Павла Тичини, Василя Барки, Івана Багряного [Ленська 2015:367-371].

Мета статті - дослідити літературну трансформацію історичної правди у художній епіці митців в екзилі про голодомор 1932-1933 рр. на прикладі творів Олени «Звичайної «Миргородський ярмарок» та Іванни Чорнобривець «Страшна весна», «В обіймах голодного міста».

Звернення до душевних станів української людини у добу національної катастрофи, до апокаліптичної ситуації фізичного винищення селянина характерне для творів Олени Звичайної (Олени Джуль) та Іванни Чорнобривець (Олександри Сулими-Блохин). Предметом зображення письменниць було не лише тоталітарне суспільство, але в першу чергу - душа селянина, його внутрішній світ у межовій ситуації, у трагічній ситуації відчаю та безвиході. Розкриваючи психологічні реалії внутрішнього стану хлібороба, авторки намагалися органічно поєднати переживання людини, яка не піддається впливу 
тоталітарному режиму 3 натуралістичним відтворенням картин самого голодомору.

Документалізм і правда про радянську дійсність з ії облудними гаслами, звинувачення комуністичній системі у нищенні українського народу декларовані у повісті Олени Звичайної «Миргородський ярмарок». Авторка вказує на причини формування психологічного тла для нищення цілих груп людей, які стали для нової влади «ворогами народу». Механізм «поступу влади рад» ознаменований антиукраїнською складовою у пропаганді, наступом на інтелігенцію та ліквідацією «українських націоналістів», вилученням продовольства i - створенням штучного голодомору, жертвами якого стали мільйони.

Герой «Миргородського ярмарку» - Михайло Семенович Самодин (прізвище несе конотативно-семантичне забарвлення - «сам один») - колись заможній селянин, який дбав про своє господарство, худобу, тепер «розкуркулений ворог колективізації», на ярмарку продає жіночу плахту. Ця плахта ще з часів Гоголя, яскрава, якій ціни немає, тепер має врятувати голодну родину діда Михайла. Авторка говорить, що дід ніколи б не продав ту плахту, проте у скрутний час, коли все збіжжя забрали нові можновладці, коли голодні внуки та дружина чекають на їжу, продаж речі для нього стає важливою справою - «раз призначивщи ціну, був твердий $i$ незламний як крицяя» [Звичайна 1953:18]. Самодин просить за плахту хлібину, «велику, добре випечену, підсмаженою икуринкою, щзо так ніжно хрумтить під зубами» [Звичайна 1953:18]. Хлібина, вимріяна ним, символ ситого життя, оживає у творі, «танщює-кокетує, як та чарівниця, обертаючись перед жадібними очима закоханого діда то тим, то іншим боком: ось глянь, мовляв, яка я добряча!» [Звичайна 1953:18]. Олюднення хлібини та відчуття іiі смаку зведено до біологічного порогового мінімуму, який переступає герой тільки у мріях, адже їжа, становлячи основу буття людини, скеровує іiї дії та вчинки. Дійсність у творі відтворена через індивідуальне сприйняття Михайла Самодина, що 
реалізується через монобачення героя, невласне пряме мовлення, авторську мову, що підсилюють інтонаційну структуру повісті.

Столітня плахта, яку вимінює на хлібину Самодин, має символічне значення - це не тільки матеріальний, але й культурний та духовний спадок його роду, бо наприкінці XIX століття в більшості регіонів України вона вийшла з ужитку, замінена спідницею. Плахта була елементом святкового одягу українців протягом майже всього XIX століття. Сакральність плахти як святкового одягу виражається у тому, що прикривала ті частини тіла дівчини, які, на думку предків, сприяли родючості майбутньої жінки, передавалася 3 покоління в покоління й була оберегом. Український одяг свідчив про майстерність наших предків: вишиванки, сорочки, плахти, запаски, в узорах якого відображена культура i характер народу, багатство духовного світу, спосіб життя, народні традиції. Краса природи, гармонія кольорів були втілені у національному одязі, виготовленому власними руками, за допомогою якого кожна жінка демонструвала свою хазяйновитість та індивідуальність. Святковий i робочий одяг був у пошані однаково, адже жінки i дівчата намагалися виглядати охайно.

Святкова (шовкова, пошита 3 срібної чи навіть золотої парчі) плахта вишивалася красивими яскравими візерунками шовковими або вовняними нитками, обшивалася багатою тасьмою. Недарма кучерява курортниця Ревека Миронівна хвалиться перед своєю знайомою Марією Іванівною плахтою, купленою за хлібину у діда Михайла, зазначаючи, що «їй же цุiни нема! Papumem!» [Звичайна 1953:31]. Таке ж сакральне значення має і вишиванка, яку купила Марія Іванівна. Енергетичний заряд вишитої сорочки передається через колір, орнамент, крій, матеріал, нитки, оздоблення й така вишиванка $\epsilon$ оберегом. Авторка досить скупо змальовує вишиванку, тільки через деталі ми маємо уявлення про рукодільний виріб та його власницю. В українському етнічному костюмі кожна деталь, кожен елемент мав символічне значення і ніс у собі певний інформаційний код. Одяг українців слугував ідеальним текстом щодо визначення регіону, вікової градації та статусу власника. Для курортників 
український одяг - це лише можливість похизуватися красивою, вишуканою річчю. Плахта - не єдина річ, що дід Михайло вимінює, раніше він вже віддав золотого хрестика у Полтаві за торбинку борошна. Хрестик для богомільних селян, християн за віросповіданням, має сакральне значення.

Мода на все українське у 30-х роках минулого століття та його популярність заполонила радянську індустрію, про що говорить Олена Звичайна: «у Москві $i$ в Ленінграді украӥнський стиль у великій моді» [Звичайна 1953:41]. Ціну цьому українському, яке в скрутний час за безцінь скуповується у голодних селян, а для московської господині облаштування помешкання в українському стилі «нічогісінько не коштує.. Hi-чо-гі-сінь-ко!» [Звичайна 1953:41], знає наймичка Ганна, для якої «кожна річ - то кусок хліба» [Звичайна 1953:41]. Авторка у «Миргородському ярмарку» подає два погляди на опозицію «голод - труднощі росту»: голод для московської еліти (курортників) всього лише «труднощі росту», за якими для Ганни тисячі мертвих, що «їх без труни, без священника... десятками в одну яму, як собак, закопують?!? Так ото від... росту люди людей їдять?»[Звичайна 1953:42]. Обурення простої селянської дівчини наростає, для неї боляче чути, що іiі родичі, які віками працювали на землі, обробляли, збирали врожаї, тепер виявилися ледарями. С. Ленська вважає, що «байдужість ситої «еліти» до тисяч голодних людей маркує подвійну мораль у радянському суспільстві. Тема Голодомору y діаспорній прозі перетворилася на художнє свідчення про злочини, здійснені тоталітарною державою проти народу, розкриті 3 допомогою експресіоністичних засобів. Реалістичність сюжетних ситуачій та образів переплітаються у текстах митц̧ів з натуралістичністю деталей, щ⿻о вибудовують моторошну картину всенародної біди» [Ленська 2015:373]. Натуралістична фіксація у «Миргородському ярмарку» сцен смерті, матеріальних реалій побуту, контрастне змалювання подій, детермінує відтворення картин злиденного життя селян, привертає увагу до проблеми людини і суспільства. 
Радянська ідеологія прикривається оманливими гаслами, маніфестами, не визнаючи голоду. Це слово, кинуте у натовпі на ярмарку викликає цілу бурю емоцій та обурення у міліціонера, який слідкує за порядком, бо не може дозволити «контр-революційних» вигуків. Дзвінкий голос жінки, яка промовила слово «голод», розчинився у натовпі, але «шептуни» (підлабузники, донощики) завжди були на сторожі (порівняння з мисливським псом є важливою деталлю у творі).

Оманливі лозунги, проголошені під час революції більшовиками, декларують свою справжню сутність і підсилюють сатиричне звучання твору, бо за радянської влади «селянство розцінюється виключно як “дрібнобуржуазна стихія”, як могутній потенціал спротиву кинуту із кремлівських башт директивам» [Звичайна 1953:26]. Гірка іронія звучить у рядках твору про нові зміни: «нове кріпацтво - колгосп» [Звичайна 1953:28], тепер «кожен колосок, кожна зернина - державні!» [Звичайна 1953:25]. Навіть крамниці змінилися й «чого тільки нема тепер у тих крамницяях» [Звичайна 1953:25-26], насміхається авторка: є тільки списки, горілка, оцет, кава-сурогат і сіль, бо «мабуть “переможному пролетаріятові” цьього досить» [Звичайна 1953:26]. Олена Звичайна констатує: «Миргород, як $і$ вся Украӥна, змінила своє обличчя» [Звичайна 1953:23], проте не в кращу сторону.

Вирок радянській владі беззаперечний: гіркий сарказм письменниці підкреслений алогізмом у характеристиці нової влади, яка закріпачила селян, ввела нові порядки i, «очолений червоним Кремлем СССР-ије краӥна незнаноӥ щее в історії людства мовчазноӥ слухняности й неперевершеного льокайства...» [Звичайна 1953:28]. Червоний терор розділив життя селян на «колись» i «тепер». Викривальний пафос ідей більшовиків звучить у рядках про становище нашого народу, адже «колишнє» закріпачення «блідне перед кривавими методами масового винищення народу в добу підсовєтського, червоного «mепер»» [Звичайна 1953:29]. IV розділ повісті побудований на контрасті змалювання картин $з$ минулого й сьогодення. Увиразнює трагедію українського селянства пейзажна картина літньої ночі, на фоні якої змальовано дітей, що 
«вигукують тужливими сопілками: “Да й (розрядка автора - С. Ж.) [Звичайна 1953:14]. Голоси дітей авторка порівнює 3 камінчиками, що кидають у воду i вони зникають. Підтекст у творі досить прозорий - так зникають голодні діти, безслідно.

Авторка з сумом констатує, що зміна влади не принесла нічого кращого селянам й за допомогою антитези проводить паралель між становищем колишніх кріпаків та сучасних колгоспників: «колись кріпак два-три дні на тиждень мав право праџювати на себе, а тепер сі трудодні совєтського кріпака належать невблаганному колгоспові... То колись - після скачування кріпаччини селянин шість днів у тижні працюював на себе; тепер він частенько сім днів у тижні віддає новому панові, який, забравши в нього землю, реманент $i$ худобу, не дає хліба й дитині...» [Звичайна 1953:28]. Новий режим письменниця порівнює 3 часами закріпачення селянства, проте ті часи видаються людям кращими. Авторська іронічна інтенція спрямована проти нової влади у Миргороді, представленої двома установами - Райуправою НКВД та «ії вірною служницею - Райміліцією», що мають численний штат працівників, «добре відгодованих $i$ добре озброєних» й більше дбають про зовнішній вигляд («усі гудзики завжди на своєму місизі») та внутрішню безпеку: «як велить “великий Сталін”» [Звичайна 1953:24-25]. Іронічне забарвлення має характеристика соціального становища тогочасного суспільства: у курортників є наймички, проте заможні селяни, які не хочуть вступати у колгосп - куркулі та вороги народу. Філософські питання сенсу буття, глибокий аналіз індивідуальної екзистенції особистості увиразнюють соціально детермінований конфлікт між владою та селянами. Власне іронія авторки спрямована на розкриття невідповідності між претензіями влади та ії реальною роллю.

Осмислення подій у соціально-психологічному плані свідчить про прагнення письменниці розкрити внутрішні протиріччя персонажів, історичну правдивість зображення голоду, аналіз буття селян, документальну основу твору. 3 сумом дід Михайло згадує своє минуле і свою сім'ю: п’ять синів, на яких покладав надію, опинилися по різні сторони політичних барикад, «один 
замучений в Ч. К. щ̧е на початках револющї̈, другий - засланий на Соловки, мабуть, уже і неживий досі, третій - колгоспник, щзо помер недавно з голоду разом із невісткою, ... а два інших іщуе й досі живуть, служать на совєтських посадах...» [Звичайна 1953:18-19]. Останні два, очевидно, не підтримують відносини з родиною, а гордий дід Михайло виправдовує себе прагненням не нанести шкоду синам, не звертається за допомогою. Авторська настанова письменниці спрямована за викриття існуючої влади i системи через реалістичне змалювання історичних подій, важкого становища селянства в часи голодомору.

3 сторічної ретроспективи Олена Звичайна звертається до твору Миколи Гоголя «Повість про те, як посварився Іван Іванович 3 Іваном Никифоровичем» (1833). Насичені яскравими кольорами картини гомінкого ярмарку у Гоголя протиставляються зображенню купівлі-продажу у повісті «Миргородський ярмарок» Олени Звичайної. На думку С. Ленської, авторка, акцентуючи «на антитезі з геніальним попередником, прагне створити повнокровну картину розорення хліборобного краю, знищцення лагідного на вдачу $i$ працььовитого народу сталінською тоталітарною машиною» [Ленська 2015:368]. Події у «Миргородському ярмарку» відбуваються у славному місті на Полтавщині, на тому славному ярмарку, оспіваному Миколою Гоголем. Гоголівська тема $\epsilon$ провідною у сюжеті твору Олени Звичайної, з нею пов’язані всі події. Для передачі «голосу базару» авторка використовує імпресіоністичну техніку: зорові та звукові образи. Проте цей «голос»у творі десакралізується, бо селяни продають (чи вірніше - вимінюють) за кусень хліба речі дорогі для них: весільний одяг, рушники, мережані сорочки, плахти, скатертини, що ними застеляли столи у свята, «речі власного вжитку, родинні скарби, яким ціни нема, реліквї̈» [Звичайна 1953:12]. Основні покупці - метушливі гомінкі курортники, протиставлені неговірким млявим селянам 3 похмурими виснаженими обличчями. Незримо присутній на миргородському ярмарку 1933 року Микола Гоголь, який разом 3 дідом Михайлом оглядає і шукає не «рушників, не сорочок $i$ не плахт», а «...рук $i$ ніг, передусім облич та очей... $i$ 
того крику душі, щуо бурхливим потоком із селянських очей виливається» [Звичайна 1953:13]. Ярмаркова симфонія втратила своє первинне значення. Життя на торговищі 3 піснями, танками, залицяннями, могоричами, медом i вином десакралізується - натомість перед читачем постає гнітюча атмосфера обміну речей на хліб, жменьку зерна. Притаманну для Гоголівського мислення амбівалентність персоніфікованого образу ночі виявляє Олена Звичайна у «Миргородському ярмарку». Зорова картина передає чарівність цієї частини доби, проте звукові образи підсилюють трагічність ситуації і нагадують, завдають невимовного болю глядачу цієї нічної картини.

Драматична доля селян-хліборобів розгортається на сторінках оповідань (дилогіï) Іванни Чорнобривець «Страшна весна» (1957) та «В обіймах голодного міста» (1963), поєднаних спільним ідейним задумом, героями. Фабульною основою творів є реальні події голодомору в України на прикладі звичайної селянської родини, що висвітлюються письменницею через бачення Одарки, берегині роду, яка намагається врятувати своїх дітей від голодної смерті в місті, але «годі було знайти якийсь закуточок на Великій Україні, де б 1933 весна не давала себе відчути гострим голодом» [Чорнобривець 1963:64]. Зруйноване життя простої селянської сім’ї: опухлий від голоду дід Панас, одвічно пов’язаний з землею, не може сидіти вдома, коли треба сіяти - йде в поле, яке для нього стає останнім прихистком (його смерть на межі власної колишньої ниви має символічне забарвлення - межа між достатком у минулому та теперішнім спустошенням); його син Іван відправляється на заробітки на шахти Донбасу; невістка Одарка, зморена голодом, після смерті двох старших дітей, з меншими йде в місто. Поневіряння, муки, передсмертні агонії натуралістично виписані в оповіданні. «Гнівна інвектива владі» (С. Ленська) що знищила народ, задекларована в образах Одарки та куми Хведори, остання божеволіє з горя й у стані афекту з’їдає своїх дітей. 3 натуралістичною виразністю авторка подає картину у хаті Хведори та картину сільського кладовища, де покійники лежали ледве притрушені землею. «Грізний похід живих кістяків» по дорозі у місто, у валці яких опинилася й 
Одарка з Маринкою та Семенком, шукаючи кращого життя, конкретизується через відтворення мук голодних селян, їх поневіряння, канібалізм й осмислюється як апокаліпсис.

Авторка експресіоністично передає моторошну картину вимирання українського селянства. Непомірні податки для селян виявляються непосильними: відібрали усю худобу, реманент, «до зернини всі засіки повимітали, так щзе і щзе давай!» [Чорнобривець 1963:57]. В оповіданнях Іванни Чорнобривець 3 фактографічною точністю описано сцени викачування хліба, агонії й муки голодних дітей, пошуки їжі, непривітні картини спустошення й вимирання сіл, сцени божевілля та людоїдства. Викривальний зміст прози письменниці декларується через зображення трагедії родини Одарки (прізвища авторка не подає, бо таких сімей по всій Україні тисячі). Гостра критика авторки звучить на адресу сільської (читай - більшовицької влади), яка позбавляє людей житла: за несплату податків («сто пудів хліба») у «священну власність» радянської влади переходить хата жінки. Ці картини розвінчують міф про «процвітаюче радянське суспільство». Поліфункціональні подробиці в оповіданні «Страшна весна» дозволили письменниці відтворити швидкоплинність почуттів Одарки, передати порухи іï душі, динаміку думок.

Документальна основа твору грунтується на тісному зв’язку українця 3 землею, з усією природою. Увиразнює картину зображення в оповіданнях «Страшна весна» та «В обіймах голодного міста» мотив дороги, недаремно всі події пов’язані з цим топосом: шлях Оксани у місто, смерть свекра в полі на межі, подорож з чоловіком на Донеччину. Образ потяга в оповіданні алюзійно відсилає до образу потяга у романі Івана Багряного «Тигролови»: у ситу й далеку північ рухалися важкі наладовані товарняки, «безконечні замкнені вагони з їхнім же дорогим збіжжям» [Чорнобривець 1963:63], які проводжали поглядом голодні селяни.

Для творів письменників діаспори характерне звернення до екзистенційних проблем: життя і смерті, самотності, відчуження, межового буття людини у тоталітарному світі, осягнення сенсу буття, свободи 
відповідальності. Превалюючим для Олени Звичайної та Іванни Чорнобривець стало екзистенційно-філософське осмислення буття людини у часи голодомору, змалювання антигуманної сутності радянської влади й проголошуваних нею фальшивих гасел, розвінчання «процвітаючого» радянського суспільства. Письменниці 3 документальною точністю та натуралістичною виразністю відтворили трагічні події національної історії, безпосередніми свідками яких були.

\section{БІБЛІОГРАФІЯ}

Звичайна 1953 - Звичайна О. Миргородський ярмарок / Олена Звичайна. Вінніпег : Тризуб, 1953. - 46 с.

Ленська 2015 - Ленська С. В. Українська мала проза 1920 - 1960-х років : ідейно-тематичні домінанти, жанрові моделі і стильові стратегії : дисертація на здобуття наук. ступеня доктора філол. наук : спец. 10.01 .01 «Українська література» / Світлана Василівна Ленська ; Київ. нац. ун-т ім. Т. Шевченка. - К., 2015. $-470 \mathrm{c}$.

Чорнобривець 1963 - Чорнобривець I. 3 потоку життя : [новели] / Іванна Чорнобривець. - Мюнхен, 1963. - 164 с.

Шумило 1995 - Шумило Н. Свідома свого обов'язку // Іванна Чорнобривець. Вибране : Поезії, новелістика, наукові та публіцистичні розвідки. - Київ : Видавництво імені Олени Теліги, 1995. - С. 5-10. 